Statement by The Managing Director on the Work Program of The Executive Board 


\section{Statement by the Managing Director \\ on the Work Program of the Executive Board \\ Executive Board Meeting \\ June 3, 2019}

This Work Program (WP) translates the strategic directions and policy priorities laid out in the Spring 2019 Global Policy Agenda (GPA) and the International Monetary and Financial Committee Communique into an Executive Board agenda for the next twelve months. ${ }^{1}$ Its main policy priorities and related deliverables are as follows:

- Support domestic policies to enhance resilience and inclusion: The World Economic Outlook (WEO) will discuss policies to sustain growth, enhance inclusion, and boost resilience. The Global Financial Stability Report (GFSR) will assess key vulnerabilities in the financial system and study the financial stability implications of US dollar funding of global non-US banks, while a staff discussion note (SDN) on Financial Services and Inequality will help to better understand how financial policies could enhance inclusion and opportunities for all. The 2019 External Sector Report analyzed the role of exchange rates in the external adjustment process. The briefing on the Integrated Policy Framework will lay out staff plans to develop a more systematic assessment of an effective policy mix by jointly considering monetary, exchange rate, macroprudential, and capital flow management policies.

- Upgrade global cooperation to level the playing field and address other shared challenges: A Stock-take on the Fund's Work on Illicit Financial Flows will provide a better understanding of such flows and discuss the issue of their quantification. The Board paper Fintech: The Experience So Far building on the Bali Fintech Agenda has taken stock of countries' fintech experiences and identify key fintech-related issues meriting further attention. Adapting National Prudential Approaches to the International Reform Agenda: Lessons from Experience will look at how economies are adapting to recent international financial sector reforms. The Fiscal Monitor (FM) analytical chapter will examine fiscal policy tools to mitigate climate change.

- Adapt the Fund's toolkits to lead and support change: The Comprehensive Surveillance Review and the Review of the Financial Sector Assessment Program will discuss how to adapt Fund surveillance to the changing environment. The Fund's debt policies will be improved through the Debt Sustainability Framework Review for Market Access Countries and the Review of the Debt Limits Policy. IMF Policies and Practices on Capacity Development was discussed following the completion of the 2018 review on the Fund's capacity development strategy.

- Continue to modernize the Fund to deliver for the future: The Board will discuss a briefing on the 2019 Diversity and Inclusion Report and the Comprehensive Compensation and Benefits Review. Briefings on the Big 5 Modernization Agenda, the Knowledge Management Strategy were held, and the Update on the IMF Communication Strategy is also scheduled.

\footnotetext{
${ }^{1}$ This WP covers FY20 (May 2019 to April 2020).
} 


\section{Key Priorities of the Spring 2019 Work Program}

Surveillance and

Policy Research

Flagships

and Thematic

Reports

Policy Research

Analytical Work Representing Staff Views

\section{Support domestic policies to enhance resilience and inclusion to benefit all}

In line with current practice, the Flagship reports will be jointly discussed ahead of the Annual and Spring Meetings. In the Fall 2019, the World Economic Outlook (WEO) will analyze the forces shaping the global outlook and discuss policies to sustain growth, enhance inclusion, and boost resilience, and the Global Financial Stability Report (GFSR) will assess key vulnerabilities in the financial system and study the financial stability implications of US dollar funding of global non-US banks. Following a technical briefing, the 2019 External Sector Report (ESR) (July 2019) presented a multilaterally-consistent assessment of the largest economies' external positions. It featured new analysis on the role of exchange rates in the external adjustment process, taking into account currency of invoicing and global value chains.

Regional Economic Briefings will provide further in-depth analyses and policy recommendations, while briefings on Global Financial Markets Developments are planned for November 2019 and May 2020. The report on Macroeconomic Developments and Prospects in Low-Income Developing Countries (LIDCs)-2019 (October 2019) will assess current macroeconomic conditions and policy challenges in LIDCs focusing on the inclusiveness of growth and sustainability of its drivers, highlighting the performance of the value added tax in revenue-generating and financial safety net arrangements. The Board will be engaged on the Early Warning Exercise in October 2019 and April 2020.

The Integrated Policy Framework will feature country experiences and analytical work on complementarities and tradeoffs among monetary, exchange rate, macroprudential, and capital flow management policies, particularly in the context of external shocks. The Board will receive an Update on the Implementation of the Framework for Enhanced Fund Engagement on Governance (March 2020) since the adoption of the framework in April 2018. Central Bank Governance After the Global Financial Crisis: In Search of Emerging Good Practices (February 2020) will analyze how challenges to central bank governance could be addressed by looking at leading practices after the global financial crisis. A Stocktake on the Fund's Work on Illicit Financial Flows (May 2020) will seek to provide a clearer understanding of illicit financial flows (IFFs) and showcase the Fund's wide-ranging IFFsrelated work streams.

The May 2019 briefing on Strengthening the Euro Area: The Role of National Structural Policies in Building Resilience was followed by a briefing on A Capital Markets Union for Europe in June. The briefing on Financial Services and Inequality (October 2019) will contribute to better understanding the interplay of financial stability, inclusion, and inequality, by studying the transmission between access to financial services and economic inequality. Political Economy of Structural Reforms (September 2019) will examine how economic policies might be adjusted to mitigate potential political costs, based on a new comprehensive database on structural reforms developed by Fund staff. Themes for additional staff discussion notes currently under consideration include the issues of fintech, 
cyber risks, competition policy, and women's economic empowerment through the role of gender budgeting.

\section{Box 1. The Fund's work on Illicit Flows}

The Spring 2019 Global Policy Agenda highlighted that a level playing field is one of the key prerequisites for moving toward a new sustainable model for international cooperation. Fighting IFFs is a transnational issue and remains an important part of this agenda. The Board paper $\boldsymbol{A}$ Stock-take on the Fund's Work on Illicit Financial Flows (May 2020) aims to:

- Showcase the Fund's wide-ranging IFF-related work, in particular on AML/CFT efforts and financial integrity more broadly, as well as tax evasion and IFF measurement and monitoring;

- Clarify the definition of illicit financial flows by distinguishing illegal flows from other flows, such as legal tax avoidance and tax planning by multinationals;

- Provide information on estimation practices and related challenges, which will be an input to the Seventh IMF Statistical Forum: Measuring the Informal Economy.

The paper will benefit from consultations with other international institutions and civil society organizations.

Global Solutions

Trade

Financial Regulation

\section{Upgrade global cooperation to level the playing field and address shared challenges}

The Fund will continue its efforts to promote open trade through policy advice and traderelated macroeconomic analyses. Staff briefs to update on recent developments in trade issues will continue as needed, including through joint work with the WTO and the World Bank (WB).

The Board was briefed in May on a Financial Stability Monitoring Framework for the GFSR, which will be followed by Latest Developments in Financial Regulation (September 2019). The Board paper Adapting National Prudential Approaches to the International Reform Agenda: Lessons from Experience (April 2020) will draw on country experiences to analyze the considerations that are guiding economies in enhancing their prudential and supervisory frameworks in the light of recent international reforms. As a follow-up work to the Bali Fintech Agenda, Fintech: The Experience So Far (June 2019) examined countries' experiences with how the financial sector is impacted by products and businesses based on new technologies and adequacy of the current legal and regulatory frameworks. The Board will also receive an Update on Trends in Correspondent Banking Relationships (March 2020). 
Development

International

Fora
The Fall 2019 Fiscal Monitor (FM) analytical chapter will delve into fiscal policies for climate change mitigation (Box 2). The Update on Implementation of Measures to Strengthen Fund Engagement in Fragile and Conflict-Affected States (November 2019) will inform the Board on the actions being taken, including in the area of HR policies, to increase the effectiveness of Fund engagement in fragile and conflict-affected states, following on from the 2018 IEO evaluation of "The IMF and Fragile States" and the Managing Director's Statement of October 2018. The Board will also be briefed on the Fund's work on Revenue Mobilization in Developing Countries (February 2020).

The Fund will continue its cooperation with other institutions and fora, and as in the past, G-20 notes will be shared with the Board for information. The joint IMF/WB G-20 note on the Operational Guidelines for Sustainable Financing-Survey Results and Policy Recommendation, issued in May, identified good creditor practices against the G-20s' operational guidelines for sustainable financing. The G-20 Report on Strong, Sustainable, Balanced, and Inclusive Growth (October 2019) will assess the G-20's progress toward its objectives and the impact of joint implementation of policy recommendations on global growth and imbalances. The Board was also briefed on Global Imbalances, followed by a G20 Note (May 2019), and the annual Progress Report of the G-20 Data Gaps Initiative will be shared in September 2019.

\section{Box 2. The Fund's work on Climate Change and Natural Disasters}

The Fund is continuing efforts to provide macroeconomic guidance on climate change mitigation and adaptation strategies and support resilience-building in countries vulnerable to natural disasters, especially small states.

- Building Resilience in Countries Vulnerable to Natural Disasters, discussed in May, considered a holistic approach to building resilience to natural disasters using a three-pillar approach that addresses building physical resilience, financial resilience, and social resilience.

- Building on the recent Board discussion on "Fiscal Policies for Implementing Paris Climate Strategies" last March, the Fall 2019 Fiscal Monitor will analyze fiscal policies for climate change mitigation, the impact of international coordination through carbon price floors, policies for investment in the transition to low-carbon energy, possible options for overcoming political economy obstacles to pricing, and the implications of global mitigation for fiscal regimes in resource-rich countries.

- Staff is also studying climate-related risks and implications for financial sector policies. This involves enhanced financial stress testing by integrating climate-related shocks with broader macroeconomic scenarios, including in non-life insurance sectors. Staff work on climate-related risks to financial stability will be discussed in the 2020 FSAP Review.

- A joint WB-IMF working group is exploring more effective coordination on Climate Change Policy Assessment (CCPA) and Disaster Resilience Strategy. The Fund is also working with the European Union on revisions to its Climate Policy. 
Fund Policies

Surveillance

Lending

Debt

Capacity

Development

IMF Finances and Governance

\section{Adapt the Fund's policy toolkits to lead and support change}

Following discussions on the scoping notes last March, work on the 2020 Comprehensive Surveillance Review (CSR) and the 2020 Review of the Financial Sector Assessment Program (FSAP; jointly with the WB) will move forward. The Board will be engaged on Midpoint notes (December 2019) and then final papers (April 2020). As groundwork for the FSAP review, the Staff Technical Briefing on the Data and Methodology Used for Updating the List of Mandatory FSAP Jurisdiction is scheduled for September. The Board will be engaged on Progress in Revising the Monetary and Financial Transparency Code (November 2019), which will revisit the experiences with the code to incorporate lessons from the global financial crisis and developments in other international standards. A formal meeting on The New Monetary and Financial Transparency Code is expected in April 2020. Based on the previous two Board discussions, the Review of the Fund's Policy on Multiple Currency Practices-Proposals for Reform is scheduled for September.

The major reviews to improve the Fund's lending policies, 2018 Review of Program Design and Conditionality and 2018 Review of Facilities for Low-income Countries-Reform Proposals, were discussed in May. Related items, including the Review of the Financing of the Fund's Concessional Assistance and Debt Relief to Low-Income Countries and Poverty Reduction and Growth Trust-Review of Interest Rate Structure have also been concluded. Staff will proceed with follow-up work to implement their outcomes. The review of Eligibility to Use the Fund's Facilities for Concessional Financing is now expected to be completed later this year, following an informal briefing in June. As announced in the previous WP, the Board will discuss Misreporting Policies-Selected Issues (February 2020), which will review aspects of the implementation of the Fund's misreporting policies.

The Board was briefed in May on the Update to the Joint WB-IMF Multipronged Approach for Addressing Emerging Debt Vulnerabilities. Going forward, two major reviews are scheduled. The Board will be engaged on the Debt Sustainability Framework for Market Access Countries in November this year, followed by a formal Board at a date to be announced. The Board will also be engaged twice on the Review of the Debt Limits Policy (May 2019 and January 2020) as currently envisaged, before the formal Board meeting in April 2020.

The Fund will continue its efforts to increase the effectiveness of capacity development and to better integrate capacity development, surveillance, and lending activities. In June 2019, the Board was engaged on the IMF Policies on Capacity Development, which updated the 2014 IMF Policies and Practices on Capacity Development given the completion of the 2018 capacity development review. The Board will also be briefed on how area departments are integrating capacity development, surveillance, and lending as part of regional briefings or stand-alone sessions, such as the AFR Capacity Development-Surveillance Integration (September 2019) and APD Capacity Development-Surveillance Integration (February 2020).

Work to ensure that Fund resources remain adequate and governance reform continues 
Quota and

Voice

IEO

IMF Finances

Internal Support

Human

Resources

Other Internal Operations

Work is underway on package of reforms that would at least maintain the Fund's current resource envelope and ensure that governance reform will continue. Board engagements will be scheduled as appropriate.

IEO evaluations will continue to strengthen the Fund's learning culture. The Board discussed the IEO evaluation report on IMF Advice on Unconventional Monetary Policies (June 2019), to be followed by the Management Implementation Plan on IEO Report on IMF Advice on Unconventional Monetary Policies (December 2019). The Board will be also engaged on the IEO shorter Evaluation focused on IMF Collaboration with the World Bank on MacroStructural Issues (March 2020). The Management Implementation Plan on the IEO Report on The IMF Financial Surveillance is scheduled for September 2019. The Periodic Monitoring Report will be discussed in November, along with a paper proposing the Categorization of Open Actions in Management Implementation Plans based on the categorization framework endorsed by the Board last February.

The Board will be briefed on The Annual Report of the Investment Account and Trust Accounts for FY2019 in August, and the Review of the Adequacy of the Fund's Precautionary Balances will be discussed in February 2020. The Review of the Fund's Income Position for FY2020 and FY2021-2022 is scheduled for April 2020.

\section{Modernize Fund operations}

The Board will further discuss the Comprehensive Compensation and Benefits Review (CCBR): Market Analysis and Policy Discussion (September 2019), followed by a formal discussion in November 2019. Additional discussions will be scheduled as necessary. Work on the human resources strategy will continue with implementation of enhanced frameworks for performance management, and career and succession management. Building on the brief on the 2019 Diversity and Inclusion Update in May, the Board will discuss the Diversity and Inclusion Report in November this year.

Multiple Board engagements on the Big 5 projects ${ }^{2}$ are envisaged. The Board was briefed in June on Big 5 Modernization Agenda, including 1 HR Business Case and Cost Benefit Analysis. The Board will also be briefed on the Budget Trends and Initiatives: Update on Big 5 Modernization Projects; Updated Capital Investment Framework (September) and receive for information the Periodic Reports on Big 5 Modernization Projects

(January 2020). Additional engagements on the Big 5 projects will be added as the work on business cases and cost-benefit analyses nears completion. Regular meetings on Budget, Income Position, and Compensation will follow before the 2020 Spring Meetings. The Board will also receive a briefing on Risk Management: Update on Information Security Posture and Roadmap in September 2019. An Update on the IMF Communications Strategy is scheduled for January 2020.

\footnotetext{
2 These are: transformation of the HR system and operating model (1HR), reformed Capacity Development Management and Administration processes (CDMAP), development of an Integrated Digital Workplace (IDW), a next generation economic data platform (iDATA), and knowledge management (KM).
} 